\title{
Triple Public Financial Appropriation - A Legal Corruption Hotbed in Chinese Public Expenditure
}

\author{
Mike XU Guang-Yi ${ }^{1}$ Diana QIU Xiao-Dan ${ }^{2}$ \\ ${ }^{1}$ University of Wales, United Kingdom \\ ${ }^{2}$ Public Policy Research Institute, Hong Kong Polytechnic University
}

\begin{abstract}
:
Chinese economic boost rely on government investment, however, legal corruption has been always hiding in huge amount of public expenditure, even start from 30 years ago after Chinese economic reform. Triple Public Financial Appropriation is one of the hotbeds for legal corruption that have been recently reviewed by the public sight from confidential state secret. The paper aim to introduce the definition of TPFA and why it attracts public concern, aim to calculate its total amount and its proportion in total public expenditure, and attend to seek the best routine control government official expense and solve this public issue.
\end{abstract}

Keywords: Legal Corruption, Public Expenditure, Financial Appropriation, China

\section{Introduction to TPFA}

Triple Public Financial Appropriation (TPFA) is a phrase with Chinese government characteristics, which refers to three kinds of public expenditure allocated to government departments: travel and visit abroad, vehicles purchase and operation, reception and hospitality.

According to report released by Chinese Ministry of Finance, there are at least 56 departments receiving direct
TPFA every year. Main and branch agencies of Chinese Ministry of Finance in central, provincial and spatiality regions are certainly involved. Affiliated institutions of Chinese Ministry of Finance, such as Payment Center, Education Center, Research Institute, Information Network Center are also included. Besides these departments under control of Chinese Ministry of Finance, Ministry of Foreign Affairs, State Council of Overseas Chinese Affairs and other central government departments also receive similar kind of financial appropriation.

\section{How TPFA attract public concern}

In a long period of time, even start from the establishment of the country till over 30 years after Chinese economic reform, Chinese official expenses are classified to "state secret". TPFA and other sensitive information are blocked out of public sight, while the tax payers do not have right to know the usage, which provide opportunity for legal corruption.

Until $23^{\text {rd }}$ Mar 2010, Chinese State Council reported its official expenses to the National People Congress Committee, and TPFA information has been presented to the public for the first time. Since then, central departments are requiring to report official public expenditure every year including TPFA. 
Although it is requested by Chinese State Council, almost $90 \%$ of the central departments refuse to present the data before the deadline, including Ministry of Foreign Affairs, State Council of Overseas Chinese Affairs, State Council of Hong Kong and Macao Affairs, State Council of Taiwan Affairs, State Tobacco Monopoly Bureau and etc.

However, facing various public pressures, these departments now gradually open their confidential official expense databases for public supervise. Compared with previous situation, open access to TPFA is a step forward for Chinese government, the policy now may partly satisfy public's right to know about official expense, and relatively reduce asymmetric information between government and the public.

\section{Total amount of TPFA}

According to statistic released Chinese Ministry of Finance, actual expense of central departments TPFA in 2010 is up to 9.470 billion RMB, 1.773 billion in travel and visit abroad, 6.169 billion in vehicles purchase and operation, 1.528 billion in reception and hospitality. In 2011, the numbers just slightly changed to 9.364 billion RMB, 1.977 billion in travel and visit abroad, 5.915 billion in vehicles purchase and operation, 1.472 billion in reception and hospitality.

When transfer these numbers into consuming type, these purchase quantities will become enormous. If each officer in central government departments share approximately 20,000 RMB in travel and visit abroad, 1.773 billion RMB will be equal to 88,650 travels in one year, which are about 243 travels per day. If transfer vehicles purchase and operation to a typical 26,000 RMB car purchase, 6.169 bil- lion will be equal to 237,269 brand-new official vehicles in one year, and that is buying 650 new cars per day. If set each welcome dinner to 10000 RMB standard, 1.472 billion in reception and hospitality can be equal to 147,200 meals per year, which is 403 reception per day.

Moreover, even with open access policy, the total amount of TPFA is apparently more than the numbers presenting right now. Local government departments have a 5.61 times financial expenditure in total compare to the central government departments, however, they are not concluded in open access range. Gray income and expenditure are hard to detected and track, which may cause inexact in TPFA calculation.

Thus, a researcher from National People Congress Committee estimated in 2004 that the real expense of annual TPFA maybe more than 900 billion RMB in total. Chinese Ministry of Finance announced this number to be "severely inconsistent with facts", saying their estimated nationwide TPFA is about 120.1 billion RMB, which provide clues for real numbers of this mysteries financial appropriation.

If using the current exchange rate that 1 U.S. dollar equal to $6.25 \mathrm{RMB}, 900$ billion RMB will be equal to 144 billion U.S. dollars. According to the latest statistics, 2 billion U.S. dollars will be spent on $45^{\text {th }}$ U.S. presidential election, and because Americans will elect a president once for four years, 900 billion RMB will be sufficient for 288 years of American presidential election. Even using the lowest estimation method to add local government departments (equal to 5.61 times of central government), 62.59 billion RMB will still be able to afford 10 times of U.S. presidential election for 40 years. 


\section{Proportion \& estimation of TPFA}

To estimated the proportion of TPFA in total public expenditure, we use the data receive direct financial appropriation from Chinese Ministry of Finance to set growth rates.

According to statistic, TPFA transfer to related department from Chinese Ministry of Finance valued 41.7201 million RMB in 2010 to 46.2077 million RMB in 2011, increase 4.4876 million RMB for balance, with annual growth rate accounted $10.75 \%$. Meanwhile, the total public expenditure has increased 1937.363 billion RMB in 2012 from 8987.416 billion $\mathrm{RMB}$ in 2010, with annual growth rate accounted $21.55 \%$, which is about 2 times the speed TPFA increased at the same period. This is the first to clue for us to set a proper growth rate of TPFA according to the growth rate of total public expenditure.

Combine a report released by Chinese Ministry of Finance in 2004, it announced an official estimation of TPFA in 2004, using the final accounts date of administrative institutions as sample, calculated a total amount of 120.1 billion RMB for national wide TPFA cost in 2004. Using these clues listed above, we are able to estimated TPFA form 1992 to 2011.

According to the estimated TPFA result base on Chinese Ministry of Finance database, the amount of TPFA estimated to grown from 41.61 billion RMB to 243 billion RMB, which rise about 6 times in 1992 to 2011; while the proportion of TPFA has been in a gradually downward trend from nearly $12.1 \%$ to $2.5 \%$ for 20 years. This amount of TPFA may still be considered to be acceptable for the public in some degrees. If using this history data to forecast future growth, TPFA will raise to 630 billion in 2021 after 10 years of average $10 \%$ growth rate, while the pro- portion of TPFA in the same year will become less than $1 \%$.

However, if using the data estimated by the researcher from National People Congress Committee, the result could be fairly different. Total amount of TPFA estimated to grown is valued from 179.75 billion RMB to 936.41 billion RMB, which only rise about 5 times in 1992 to 2011; but the lowest proportion of TPFA to public expenditure maybe about $9 \%$ and the highest may skyscraper to more than $51 \%$. This amount of TPFA is totally unacceptable for the public. If using this estimated data to forecast future growth, TPFA will raise to 2428 billion in 2021 after 10 years of average $10 \%$ growth rate, while the proportion of TPFA in the same year will keep descending to less than $4 \%$.

\section{Suggestion to control TPFA}

Financial expenditure experts accepted the fact that the definition of TPFA is not accurate indeed, which lead to all available TPFA data are calculated with unified and various standards in statistics and mostly only provide general instead of detail information. What make the situation worse is, all these data are calculated and presented by the departments themselves, and the public is convinced that money spenders themselves will never be honest enough to let the public know the real cost.

Some financial regime designers suggest introducing an independent third-party audit agency to supervise TPFA. However, it is unlikely to become reality base on current Chinese political environment. Even if independent third-party audit agency did get involve in the system, huge gray zone and extra-budgetary expenditure, like a black hole, will still cause uncertainty in TPFA data analysis. 
That is just one of the reasons why TPFA has become hotbeds of corruption, lack of accountability to justify these officials make the situation more complex, which cause cases even when problem has exposed, no one have to take the responsibility. For example, Ministry of Water Resources spent 8,312.81 million RMB for official vehicles in 2011, which accounting for $80.26 \%$ of the total TPFA. After this news was released, neither did minister of Water Resources explain to the public about this issue, nor did he been punished or questioned by State Council.

Thus, strict monitoring system, clear financial discipline, substantial accountability mechanisms and resign responsibility are vital for control official corruption. Surprisingly, Chinese government system design is not lack for such regime. Back to 1989 , Chinese State Council has already mentioned accountability regime in provisional rules particularly serious accident investigation. In 1995, Chinese communist party also issues a regulation for officials' selection and resignation. In 1998, implementation for provisions of Clean and Honest Administration also made several sample cases for responsibility regime.

This touches the reality of Chinese law system implantation, a phenomena called: failure to abide law, lack of executive in law enforcement and impunity after breaking law. To the case of corruption control, neither did law been strictly en- force to universal acknowledge, nor did the application of law forming practice in daily supervision process. This is the typical law term named "law dummy", meaning law become non-existent and weak before the pressure of power. Similarly, law design to restrict government officials may also become powerless due to their special identities. Try to avoid law dummy phenomena is necessary for effective government and social progress.

\section{References}

[1] Ministry of Finance of the People's Republic of China. Finance Year book of China 2004. China Finance Periodical Office. Beijing. 2005

[2] National Bureau of Statistic of China. China Statistical Yearbook 2011. China Statistical Periodical Office. Beijing. 2012.

[3] National Bureau of Statistic of China. China Statistical Yearbook 2004. China Statistical Periodical Office. Beijing. 2005.

[4] Official website of Ministry of Finance of the People's Republic of China. www.mof.gov.cn

[5] Xu Hui, Li Dan. Chinese annual consumption of nearly 900 billion RMB is a false message. 2006-4-19. http://www.people.com.cn/

[6] Zhu Li Jia. Several starting points of government management reform. Study Times. 2006-3-13 